\title{
Predicting Well-Being and Life Satisfaction in Colombian Adolescents: The Role of Emotion Regulation, Proactive Coping, and Prosocial Behavior
}

\section{Predicción del Bienestar y la Satisfacción con la Vida en Adolescentes Colombianos: El Papel de la Regulación Emocional, el Afrontamiento Proactivo y la Conducta Prosocial}

\author{
Karen Ripoll-Núñez, Sonia Carrillo, and Yvonne Gómez \\ Universidad de los Andes \\ Johny Villada \\ Universidad de Antioquia
}

\begin{abstract}
The aim of this study was to evaluate the association between positive competences, such as emotion regulation, proactive coping and prosocial behavior, and Colombian adolescents' perception of their well-being and life satisfaction. Through a convenience sample, $9307^{\text {th }}$ and $9^{\text {th }}$ grade adolescents attending 11 public and private schools in 2 main cities of Colombia answered to a set of scales that evaluate proactive coping, emotion regulation, prosocial behavior, perceived life satisfaction and well-being. Multiple linear regression analyses were conducted to evaluate models for adolescents' well-being and life satisfaction, with the positive competences taken as predictive variables. The model that showed the best fit and accounted for the greatest amount of variance in adolescents' well-being and life satisfaction included 2 dimensions of proactive coping (positive and social), emotion regulation and prosocial behavior. Recommendations for future research and the development of intervention programs to promote adolescents' well-being are presented.
\end{abstract}

Keywords: adolescents' well-being, life satisfaction, emotion regulation, proactive coping, prosocial behavior

\begin{abstract}
El propósito de este estudio fue evaluar la asociación entre competencias positivas, como la regulación emocional, el afrontamiento proactivo y la conducta prosocial, y la percepción de adolescentes colombianos sobre su bienestar y satisfacción con la vida. A través de una muestra por conveniencia, 930 estudiantes de $7^{\circ}$ y $9^{\circ}$ grado de 11 colegios públicos y privados de 2 ciudades principales de Colombia respondieron una serie de escalas que miden regulación emocional, afrontamiento proactivo, conducta prosocial, satisfacción con la vida y bienestar. Se realizaron análisis de regresión lineal múltiple para evaluar modelos del bienestar y la satisfacción con la vida, considerando las competencias positivas como variables predictoras. El modelo que mostró el mejor ajuste y mayor varianza explicada incluyó 2 dimensiones del afrontamiento proactivo (positivo y social), la regulación emocional y la conducta prosocial. Recomendaciones para futuras investigaciones y el desarrollo de programas de intervención para promover el bienestar en adolescentes son presentadas.
\end{abstract}

Palabras clave: bienestar adolescente, satisfacción con la vida, regulación emocional, afrontamiento proactivo, conducta prosocial

The study of children and adolescents' well-being became an important research area to different professionals during the last decade (Ben-Arieh, Casas, Frønes, \& Korbin, 2014; De Castella, Goldin, Jazaieri, Ziv, Dweck \& Gross, 2013; Garbarino, 2014; Gillham et al., 2011). A prevalent paradigm on adolescent research has been a deficit or problem-based model (Damon, 2004), which characterized youngsters as "broken or in danger of becoming broken, and as problems to be managed" (Lerner, 2005, September, p. 3). Congruent with this view, researchers and professionals interested in adolescent

Karen Ripoll-Núñez, Sonia Carrillo, and Yvonne Gómez, Departamento de Psicología, Universidad de los Andes, Bogotá, Colombia; Johny Villada, Departamento de Psicología, Universidad de Antioquia, Medellín, Colombia.

Correspondence concerning this article should be addressed to Karen Ripoll-Núñez, Departamento de Psicología, Universidad de los Andes, Cra 1 \# 18A-12-2 ${ }^{\circ}$ Piso Of.221. E-mail: kripoll@uniandes.edu.co 
development mainly focused on intervention programs oriented to fix or remediate those problems. A research approach on adolescence that included strengths and competences was not frequently found in the literature and the promotion of positive attributes was neglected for several decades.

The present research sought to contribute to the study of adolescents' health and positive development. Its main purpose was to assess Colombian adolescents' positive competences, such as emotion regulation, proactive coping, and prosocial behavior, and to examine their association with youths' perceptions of their well-being and life satisfaction. This study followed two main approaches: First, a salutogenic perspective, that emphasizes the study of adolescents' health based on the resources and competences they use to cope with difficult conditions and help them to stay or become healthier (Antonovsky,1988, cited in Sagy, Eriksson, \& Braun-Lewensohn, 2015); and second, the positive youth development approach proposed by Lerner, Almerigi, Theokas and Lerner (2005, September). According to these authors the possibilities for a healthy development are linked to adolescents' strengths and positive resources; these competences arise within the main significant contexts in which children develop (i.e., family and school; Lerner et al., 2005).

Lerner's perspective is congruent with positive psychology assumptions that highlight the importance of strengthening virtues and positive competences as a way to enhance individuals' development (Alarcón Napurí, 2009; Seligman, 2002; Seligman \& Pawelski, 2003). Empirical studies in the United States and Europe suggest significant correlations between different positive competences and adolescents' psychological functioning and well-being (Casas, Bello, González, \& Aligué, 2012; Goswami, 2012; Lau, Cummins, \& McPherson, 2005; Tomyn \& Cummins, 2011). In Latin America, the literature on children and adolescents' life satisfaction and well-being has mainly been developed in the last decade. Research has focused on psychometric studies of instruments designed to evaluate satisfaction with life and well-being (Alfaro et al., 2016; Padrós Blázquez, Gutiérrez Hernández, \& Medina Calvillo, 2015; Vera-Villarroel, Córdova-Rubio, \& Celis-Atenas, 2012) and on the role of positive competences on youths' quality of life and well-being (Casas et al., 2014; Castellá Sarriera, Saforcada, Tonon, Rodríguez de La Vega, Mozobancyk, \& Bedin, 2012; Oyanedel, Alfaro, Varela, \& Torres, 2014; Verdugo-Lucero et al., 2013). In Colombia, the literature on adolescents' positive functioning is limited. Researchers have begun to explore adolescents' strengths and their relation to quality of life (Quinceno \& Vinaccia, 2104a, 2014b) and the psychometric properties of instruments to assess well-being (Pineda Roa, Castro Muñoz, \& Chaparro Clavijo, 2018; Tuesca-Molina, Centeno Romero, de la Ossa Salgado, García Delgado, \& Lobo López, 2008). However, this line of research is still in its early stages; more studies on Colombian adolescents' positive functioning are required.

The need to evaluate individual competences associated with well-being and life satisfaction in Colombian adolescents has become more relevant, as national surveys have revealed current social and psychological issues that must be included in the social policy agenda. In particular, a recent study on youth (14 through 25 years) in Colombia, which was based on a sample of over 2000 participants across the country's five geographical regions, evaluated both risks and resources that affect youth's well-being (British Council, Universidad de los Andes, \& Universidad del Rosario, 2018). Depending on the geographical area and the context (urban or rural) where youth live, they are exposed to social and political violence, community violence and crime (e.g., gangs), and family violence. Results indicated that $43 \%$ of youth living in urban areas and $22 \%$ living in rural areas have been victims of crime. Youth in Colombia also reported the following issues in their communities: alcohol abuse (42\%), other drugs use (36\%), and teen pregnancy (40\%). In addition to risks, this study also assessed youth's resiliency—which was defined as personal, relational and contextual resources that promote individuals' well-being-in rural and urban areas across the country. Youth's scores indicated that $40 \%$ had low or very low resiliency and most of those youth with low resiliency scores lived in the most populated cities in the country or in towns nearby. More importantly, results indicated that youth with low resiliency scores lacked primarily contextual resources and support networks that help them maintain a sense of well-being (British Council et al., 2018).

Results from this study suggest that individual (psychological) resources are key in youth's resiliency and the maintenance of a positive sense of well-being. Therefore, this study on the social and psychological needs and resources of Colombian youth highlights the importance of evaluating the role of positive individual competences in maintaining well-being (British Council et al., 2018). However, studies in Colombia have not evaluated the specific contributions of different individual resources (e.g., coping skills, prosocial behavior, and emotion regulation) in adolescents' positive views on well-being and life satisfaction. 
Another reason for studying adolescents' competences is the increasing rates in mental health issues during this life period that demand the development of preventive programs. The World Health Organization (WHO)'s report on children and adolescents' mental health indicates that $10-20 \%$ of youths worldwide experience mental health issues, such as depression, anxiety, and eating disorders. Similarly, adolescents' mental health issues in Latin American countries show prevalence rates between 12.7 and 15\% (WHO, 2017). In Colombia, suicide attempt rates among adolescents (ages 15 through 19) increased from 2.5 to $7.5 \%$ between 2009 and 2015. Also, during the same time period, adolescents between 15 and 19 years reported higher rates of depression and anxiety than other age groups (Colombia, Ministerio de Salud, 2017).

As a result of the increasing rates in mental health issues, health organizations have highlighted the importance of strengthening positive competences in the prevention of mental health difficulties in adolescence. WHO experts conclude that enhancing social skills, as well as coping and problem-solving skills, is key in the prevention of mental health problems in adolescence (WHO, 2017; WHOQOL Group, 1995). As will be discussed later, current public policies and programs to deal with mental health issues in adolescence in Colombia seek to develop an integrated model of services that combines prevention, early detection, and treatment of most prevalent issues, such as suicide attempts, depression, and anxiety (Colombia, Ministerio de Salud, 2017). However, there is a need for research on positive competences that are associated with Colombian adolescents' well-being to provide evidence for making informed decisions on how to guide prevention efforts in both the health and education systems.

\section{Adolescents' Well-being and Life Satisfaction}

The study of well-being has followed two approaches. One is the initial conceptualizations of well-being, mainly focused on the study of objective factors which involve the presence or absence of different aspects necessary to fulfil individuals' basic needs (i.e., material circumstances, economic factors, living conditions). Other researchers understand well-being as a concept that comprises different dimensions, some focused on objective aspects of individuals' lives, while others concentrated on subjective dimensions of human functioning. Casas et al. suggest that the construct of psychological well-being should incorporate both, subjective experiences and feelings about life conditions (Ben-Arieh, Casas, Frones, \& Korbin, 2014; Casas et al., 2007; Casas et al., 2012). Following Ryff and Keyes (1995), the present study conceptualized wellbeing as a multidimensional construct that focuses on the development and enhance of strengths that contribute to individuals' personal growth and positive functioning (Ben-Arieh et al., 2014). This conceptualization is congruent with the positive youth development perspective that views adolescence as a stage characterized by numerous resources and strengths that need to be recognized and promoted (Durlak \& Weissberg, 2011).

With the emergence and consolidation of positive psychology, variables related to strengths and competences, such as satisfaction with life, started to be incorporated in the research on children and adolescents functioning (Huebner, Suldo, Smith, \& McKnight, 2004; Proctor, Linley, \& Maltby, 2009). In the literature, life satisfaction has been conceptualized as one of the indicators of individuals' global assessment of their quality of life that involves a balance between the positive and negative affect (Diener, 1984; Veenhoven, 1994). Satisfaction with life has been defined as "a global assessment of one's life as a whole that goes beyond the sum of satisfying events related to different domains of life" (Casas Aznar et al., 2004 , p. 5). Some authors have defined life satisfaction as "the cognitive component of subjective well-being" (Zuffianò, Martí-Vilar \& López-Pérez, 2018, p. 17). Recent studies have shown that children and adolescents' perceptions of life satisfaction are positively associated with particular aspects of their immediate social contexts (i.e. family and school). For instance, studies show significant correlations between life satisfaction and children's academic achievement, perceptions of abilities to solve academic tasks, and perceptions of challenges in the school setting (Alfaro et al., 2016; Antaramian, Huebner, \& Valois, 2008; Mesurado, 2010). Other studies have shown that satisfaction with life is associated with selfesteem and social support (Slatcher \& Trentacosta, 2012; Ye, Yu, \& Li, 2012). There is also some empirical evidence on the differences in life satisfaction according to age, with children reporting higher satisfaction than adolescents (Tomyn \& Cummins, 2011); and by sex, with girls showing lower satisfaction than boys (Levin, Dallago, \& Currie, 2012). However, González-Carrasco et al. (2019) have pointed out that such results are inconclusive. 
RIPOLL-NÚÑEZ, CARRILLO, GÓMEZ, AND VILLADA

\section{Predictors of Well-being and Life Satisfaction in Adolescence}

Which positive qualities need to be developed in order to foster children and adolescents' positive development? This question became the aim for many researches within the positive development movement. Studies on children and adolescents indicated that positive competences are linked to academic and social achievements and contribute to increasing well-being during the school years. Furthermore, competences such as self-control, self-regulation, hope and purpose in life are directly associated with positive youth development (Bowers, Geldhof, Johnson, Lerner, \& Lerner, 2014). Similarly, adolescents' positive development seems to be related to engagement in school activities, social support, and positive close relationships within the family and the school (Kurtines et al., 2008; Lerner, Lerner, von Eye, Bowers, \& Lewin-Bizan, 2011). Some researchers, following the character strengths model (values in action classification) proposed by Peterson and Seligman (2004), evaluated the specific role of different types of strengths in predicting adolescents' positive outcomes. In this line, Gillham et al. (2011) found that strengths such as hope, gratitude, and a sense of meaning contribute to explaining variations in North American adolescents' well-being.

\section{Emotion Regulation}

In the search for the key positive competences that influence developmental trajectories early in life, questions regarding the role of emotion regulation and specific coping skills called the attention of other researchers (Gratz \& Roemer, 2004). Emotion regulation refers to a multidimensional process responsible for monitoring, assessing, and adjusting emotional reactions in order to fulfil individual goals and to facilitate social adaptation. It is also defined as the ability to understand and express emotions in daily interpersonal situations (Cole, Martin, \& Dennis, 2004; Guzmán-González, Trabucco, Urzúa, Garrido, \& Leiva 2014; Jadue, 2003; Thompson, 2011).

De Castella et al. (2013) reported that implicit beliefs and cognitive reappraisals influence the relationship between youths' emotion regulation and well-being. Haga, Kraft, and Corby (2009) found that the way individuals regulate their emotions may have a positive or negative effect on their well-being; specifically, emotion regulation strategies, such as emotional stability and emotional control, are directly associated with well-being outcomes, particularly with high self-esteem, positive perceptions of self and others, and with high life satisfaction in adolescents and young adults (Bermúdez, Álvarez, \& Sánchez, 2003; Salguero, Fernández-Berrocal, Ruiz-Aranda, Castillo, \& Palomera, 2011). On the other hand, low indices of emotion regulation strategies have been associated with externalizing behaviors, such as verbal and physical aggression (Garaigordibil \& Oñederra, 2010; Inglés, Torregrosa, García-Fernández, MartínezMonteagudo, Estévez, \& Delgado, 2014).

\section{Proactive Coping}

The strategies children and adolescents use to cope with daily situations may either facilitate or hinder the achievement of personal goals and individual success. Active coping can be understood as the individuals' efforts to develop and maintain active ways to face situations and to cope with difficulties in daily experiences (Greenglass, 2002). Researchers, such as Frydenberg and Lewis (2009), have specifically studied the role of active coping in adolescents' functioning; they found that active coping strategies, such as planning, positive appraisals, problem solving, and hard work are directly associated with youngsters' physical health and well-being. Coping strategies, such as problem solving and search for help and social support, are also directly associated with high levels of well-being in Spanish adolescents (MayordomoRodríguez, Meléndez-Moral, Viguer-Segui, \& Sales-Galán, 2015). Viñas Poch, González Carrasco, García Moreno, Malo Cerrato, \& Casas Aznar (2015) also conducted a study to assess coping styles in a sample of Spanish adolescents, exploring sex and age differences in youths' strategies to face daily events and the relation between coping strategies and well-being. Results of this study indicated that productive coping strategies, such as focusing on positive things and physical distraction were directly associated to adolescents' well-being, while self-guilt and keeping things to themselves (non-productive coping strategies) were inversely associated to it. These authors also found age and sex differences in adolescents' well-being: it tended to decrease from early (12 years of age) to late adolescence and in girls it was associated to higher preoccupation and lower physical distraction. In Latin America, studies on coping strategies in children and adolescents are limited. 


\section{Prosocial Behavior}

Traditionally, the literature on adolescent development has shown numerous studies on antisocial rather than prosocial behavior. However, in the last decades this tendency has been changing and studies as well as programs oriented toward children and youth's prosocial behavior are increasing. Prosocial behavior has been defined as a positive and voluntary action that benefits others; it involves helping, cooperating, providing support, and being altruistic (Eisenberg, Fabes, \& Spinrad, 2006; Martorell, González, Ordóñez, \& Gómez, 2011). Findings from different studies show that prosocial behavior is associated with academic motivation, empathy, positive emotions, protective behaviors, and resilience. For instance, Inglés, Benavides, Redondo, et al., (2009) found direct associations between high school adolescents' prosocial behavior and their academic success; these associations were stronger in female than in male adolescents. Other studies report associations between cooperative behavior and empathy in antisocial adolescents and between prosocial behavior, empathy, leadership, and self -control in adolescent women (Arias Gallegos, 2013; Garaigordobil \& García de Galdeano, 2006). There is evidence in the literature of direct associations between prosocial behavior and life satisfaction; positive and reciprocal interactions and social links with others are associated with adolescents' and young adults' life satisfaction and a meaningful life (Caprara, Steca, Zelli, \& Capanna, 2005).

In summary, literature on individuals' functioning in the last decades has adopted a strength-based approach and studies are focusing on the role of positive competences in people's life satisfaction and wellbeing. Although initial studies on this area tended to focus on adults, in recent years developmental psychologists and researchers in the positive psychology field are expanding their focus to early stages of life. The strength-based approach represented an important turning point in the study of human development and well-being; the interest on this topic has significantly increased as has the number of research studies. However, studies on children and adolescents' strengths and well-being have been mainly conducted in the United States and in European countries. From a developmental view, research studies on well-being and life satisfaction in childhood and adolescence in Latin America and in Colombia are needed. Different positive competences have been associated with adolescents' well-being and life satisfaction. However, most of the studies in this area assess these variables independently. Therefore, it is important to assess the unique contribution of each one of these competences by evaluating a model that includes them all.

The purpose of this study was to evaluate the association between positive competences, such as emotion regulation, proactive coping, and prosocial behavior, and perceptions of well-being and life satisfaction among Colombian adolescents. The main research question was: How are competences, such as emotion regulation, proactive coping and prosocial behavior associated with Colombian adolescents' wellbeing and life satisfaction?

Based on the research model, it was hypothesized that:

- Positive coping, social coping, and prosocial behavior have a direct association with adolescents' wellbeing and life satisfaction, when the contributions of other variables in the model are controlled for.

- Emotion dysregulation has an inverse association with adolescents' well-being and life satisfaction, when the contributions of other variables in the model are controlled for.

\section{Method}

The present study was based on a quantitative methodology that followed an exploratory and crosssectional design with a sample of high school adolescents.

\section{Participants}

Nine hundred and thirty adolescents from two major cities in Colombia (Bogotá and Medellín) participated in the study. Participants were selected from six schools (three private and three public) in Bogotá, and five public schools in Medellín through a convenience sampling. All students in each classroom were invited to participate in the study, and they did so if their parents gave their informed consent. There were no additional exclusion criteria. Seventy percent of the sample $(n=651)$ lived in Bogotá and $30 \%$ in 
Medellín. In Bogotá, participants' average age was 13.8 years $(S D=1.32)$, whereas in Medellín participants were 13.9 years on average $(S D=1.35)$. In both cities, the sample was fairly balanced with regard to sex and school grade. In Bogotá, $43.3 \%$ of participants were males and 56.7\% were females. Also, 52.7\% were $7^{\text {th }}$-grade students and $47.3 \%$ were in $9^{\text {th }}$ grade. Similarly, in Medellín, $45.9 \%$ of the sample were males and $54.1 \%$ were females. Fifty-two percent of participants were $7^{\text {th }}$-grade students and $48 \%$ were $9^{\text {th }}$-grade students. Approximately $60 \%$ of participants' households were low to middle class and $40 \%$ were uppermiddle to upper class.

With regard to participants' family composition, approximately $73 \%$ of adolescents in Bogotá and $27 \%$ in Medellín lived with two parental figures (i.e., biological or stepparents). In two-parent families, parents' age and education levels varied across cities. In Medellín, mothers were 41 years on average $(S D=7.8)$ and fathers' average age was 44 years $(S D=7.3)$. Also, $53 \%$ of mothers and $47 \%$ of fathers had high school education, while $18 \%$ of mothers and $31.6 \%$ of fathers had college education. In Bogotá, mothers' average age was 36 years $(S D=13.9)$ and fathers were 39.7 years on average $(S D=14.8)$. Also, $29.7 \%$ of mothers and $30 \%$ of fathers had a high school education, while $33 \%$ of mothers and $32 \%$ of fathers had a college degree. Approximately 16\% of participants in Bogotá and 25\% in Medellín reported that they lived with a grandparent figure. Also, 53\% of adolescents in Bogota and 60\% in Medellín reported that they lived with at least one sibling figure.

\section{Instruments}

Demographic questionnaire. Participants responded to a brief demographic questionnaire that included questions about their sex, age, school grade and family composition.

Psychological Well-being Scale (BIEPS; Casullo \& Castro Solano, 2000). This scale measures the psychological well-being. The original 13-item instrument was developed in Spanish in Peru and evaluates four dimensions: Control of Situations (4 items; e.g., If I am upset about something I can think how to change the situation), Psychosocial Bonds (3 items; e.g., I have friends in whom I can trust), Projects (3 items; e.g., I care about what I will do in the future), and Self-acceptance (3 items; e.g., I get along well with people). Individuals respond to items on a three-point Likert type scale $(1=$ Disagree, $3=$ Agree $)$. Higher scores indicate higher levels of well-being. Because the goal was to assess the effect of different factors on adolescents' overall well-being, a total BIEPS scale score was calculated. Cronbach's alpha coefficient for the total scale in our study was 0.68 , but the Omega coefficient was 0.81 . This value indicates an adequate internal consistency.

Multidimensional Students' Life Satisfaction Scale (MSLSS; Gilman, Huebner, \& Laughlin, 2000). This instrument evaluates life satisfaction and the Spanish version was used (Galindez \& Casas, 2011). The MSLSS is a 40-item inventory that evaluates respondents' satisfaction with different domains: Family (7 items; e.g., I enjoy being at home with my family), Friends (9 items; e.g., My friends treat me well), School (8 items; e.g., I like being in school), Living Environment (9 items; e.g., I like my neighborhood), and Self (7 items, e.g., I am a nice person). Individuals respond to items on a four-point Likert type scale $(1=$ Never, $4=$ Almost always). Higher scores indicate higher levels of life satisfaction. Because the goal was to assess the effect of different factors on adolescents' overall life satisfaction, a total MSLSS scale score was calculated. Cronbach's alpha coefficient for the total scale in this study was 0.79 and 0.81 for the Omega coefficient. This value indicates adequate internal consistency.

Proactive Coping Inventory for Adolescents (PCI-A; Greenglass, Schwarzer, Jakubiec, Fiksenbaum, \& Taubert 1999). Proactive coping. was measured using a Spanish translation of the inventory (Gutiérrez-Doña, Greenglass, \& Schwarzer, 2002). This is a 55-item questionnaire that evaluates seven dimensions: Proactive Coping (14 items; e.g., I am a "take charge" person), Reflective Coping (11 items, e.g., I imagine myself solving difficult problems), Strategic Planning (4 items, e.g., I often find ways to break down difficult problems into manageable components), Preventive Coping (10 items, e.g., I plan for future eventualities), Instrumental Support Seeking (8 items, e.g., I try to talk and explain my stress in order to get feedback from my friends), Emotional Support Seeking (5 items, e.g., When I am depressed I get out and talk to others), and Avoidance (3 items, e.g., If I find a problem too difficult sometimes I put it aside until I am ready to deal with it). Individuals respond to items on a four-point Likert type scale $(1=$ Not at all true, $4=$ Completely true). Higher scores indicate higher levels of each type of coping. Exploratory factor 
analyses were conducted in the present study and revealed high correlations between the Proactive, Preventive, and Reflective coping scales (Pearson $r$ 's ranged from 0.52 to 0.62), as well as a high correlation between the Emotional and Instrumental Support scales $(r=0.71)$. Based on the results from previous research (Roesch et al., 2009) that support a better fit of a three-factor model, three subscales were calculated for this study: Positive Coping (composed of Preventive, Proactive and Reflective Coping items), Social Coping (encompassing Emotional and Instrumental Support Seeking), and Negative Coping (Avoidance). Cronbach's alpha coefficients for the subscales in the sample of this study ranged from 0.70 to 0.75, indicating adequate internal consistency, and the Omega coefficient for the whole scale was 0.92.

Difficulties in Emotion Regulation Scale (DERS; Gratz \& Roemer, 2004). For this study the Spanish version of the instrument was used (Hervas \& Jodar, 2008). The DERS is a 36-item inventory that assess difficulties in different dimensions of emotion regulation: Awareness and Understanding of Emotions (7 items; e.g., I am attentive to my feelings [reverse-scored]), Acceptance of Emotions (6 items, e.g., When I am upset, I feel ashamed with myself for feeling that way), Engaging in Goal-directed Behavior (5 items, e.g., When I am upset, I have difficulty concentrating), Refrain from Impulsive Behavior (6 items, e.g., When I am upset, I lose control over my behaviors), Access to Emotion Regulation Strategies (6 items, e.g., When I am upset, it takes me a long time to feel better), and Lack of Emotional Clarity ( 4 items, e.g., I have no idea what I am feeling). Individuals respond to items on a five-point Likert type scale $(1=$ Almost never, $5=$ Almost always). Higher scores indicate more difficulties in the emotion regulation dimensions. Because the goal for this study was to evaluate the effects of lack of emotion regulation on life satisfaction and psychological well-being, only a total DERS scale score was calculated. Previous research on the instrument that showed strong evidence of construct validity for a total DERS scale score (Weinberg \& Klonsky, 2009) was followed. Cronbach's alpha coefficients for the subscales in the sample of this study ranged from 0.66 to 0.84 , and the value for the total scale was 0.90 for the Cronbach's alpha coefficient and 0,91 for the Omega coefficient. These values indicate adequate internal consistency.

Teenage Inventory of Social Skills (TISS, Inderbitzen \& Foster, 1992). The Spanish version of this instrument was used to measure prosocial behavior (Inglés, Méndez, Hidalgo, Rosa, \& Orgilés, 2003). The TISS is 40 -item instrument that measures positive (20 items; e.g., I listen when other guys want to talk about a problem) and negative (20 items; e.g., I laugh at other guys when they make mistakes) social behaviors. Individuals respond to items on a six-point Likert type scale $(1=$ Does not describe me at all, $6=$ Describes me totally). Because the interest was only in prosocial behaviors, only items on the positive social behavior scale were used. Higher scores on this scale indicate higher levels of positive social behaviors. Cronbach's alpha and Omega coefficients for the positive social behavior subscale in this sample was 0.86. This value indicates an adequate internal consistency.

\section{Procedure}

All study procedures received the approval of the research ethics committees at the universities where the authors are currently affiliated. Permission from school principals to contact parents of $7^{\text {th }}$ and $9^{\text {th }}$ grade students were obtained. Parents received a letter that explained the study goals and procedures. A total of eighty percent of parents who were contacted in both cities gave their informed consent for their children's participation. After parents signed the consent form, school classrooms were visited, and students were explained the study goals. Students gave their assent to participate before they responded to the questionnaire packet in the classroom. The questionnaire packet included the instruments in the same order described in the section above. On average, participants responded the questionnaire packet in 40 minutes. Data were collected from July 2014 to July 2015. Either the principal investigators or trained undergraduate and graduate assistants were responsible for administering the questionnaires to participants in their classrooms.

\section{Data Analyses}

First, descriptive statistics (mean, standard deviation) were calculated and normal distribution of data in each of the variables was evaluated using the Kolmogorov-Smirnov test with Liliefors correction. Secondly, in order to evaluate the association between variables, a correlation analysis was conducted using 
the Spearman's Rho statistic due to the results of the normality test. Thirdly, a multiple linear regression analysis was_conducted to evaluate the hypothesized models. A stepwise method that selects the variables based on their relevance for the model (estimated through the correlation coefficient) was used, starting with the most relevant variable and adding the others. It is known that the coefficient of determination increases whenever an independent variable is included. Therefore, the Durbin-Watson test was used to establish independence error which indicates the level of auto correlation between the predictors' errors. Also, the relationship between the independent variables could reduce the predictive capacity of the regression models. Therefore, the values for the variance inflation factor (VIF) were examined for each of the estimated models. Data were analyzed with the SPSS 23.0 software for Windows.

\section{Results}

Table 1 presents the descriptive statistics for the measured variables. Based on these data, adolescents showed adequate levels of psychological well-being, life satisfaction, and appropriate expected scores in the evaluated positive competences.

Table 1

Descriptive Statistics for the Study Variables

\begin{tabular}{lrrrrr}
\hline \multicolumn{1}{c}{ Variable } & Mean & SD & Median & Min & Max \\
\hline Psychological well-being & 34.51 & 2.72 & 35 & 28 & 39 \\
Life satisfaction & 115.34 & 11.33 & 115 & 87 & 142 \\
Prosocial behavior & 74.71 & 11.22 & 75 & 47 & 100 \\
Emotion regulation & 76.51 & 19.92 & 77 & 31 & 123 \\
Positive coping & 122.08 & 12.56 & 123 & 89 & 153 \\
Avoidant coping & 8.67 & 1.93 & 9 & 4 & 13 \\
Social coping & 39.51 & 6.92 & 40 & 21 & 52 \\
\hline
\end{tabular}

As can be seen in Table 2, the correlations between positive competences and both psychological wellbeing and life satisfaction are significant and in the expected direction. The variable negative coping was not included in the regression models (for both psychological-wellbeing and life satisfaction), because its correlation with these variables was less than 0.20 .

Table 2

Correlations Between Variables

\begin{tabular}{|c|c|c|c|c|c|c|c|}
\hline & $\begin{array}{l}\text { Psychological } \\
\text { well-being }\end{array}$ & $\begin{array}{c}\text { Life } \\
\text { satisfaction }\end{array}$ & $\begin{array}{l}\text { Prosocial } \\
\text { behavior }\end{array}$ & $\begin{array}{l}\text { Emotion } \\
\text { regulation }\end{array}$ & $\begin{array}{l}\text { Positive } \\
\text { coping }\end{array}$ & $\begin{array}{l}\text { Negative } \\
\text { coping }\end{array}$ & $\begin{array}{l}\text { Social } \\
\text { coping }\end{array}$ \\
\hline $\begin{array}{l}\text { Psychological } \\
\text { well-being }\end{array}$ & - & $0.51^{* *}$ & $0.28^{* *}$ & $-0.25 * *$ & $0.51^{* *}$ & $0.09 *$ & $0.28 * *$ \\
\hline Life satisfaction & & - & $0.32^{* *}$ & $-0.20 * *$ & $0.42^{* *}$ & $0.13^{* *}$ & $0.37 * *$ \\
\hline $\begin{array}{l}\text { Prosocial } \\
\text { behavior }\end{array}$ & & & - & $0.10 * *$ & $0.38^{* *}$ & $0.17^{* *}$ & $0.47^{* *}$ \\
\hline $\begin{array}{l}\text { Emotion } \\
\text { regulation }\end{array}$ & & & & - & $-0.14^{* *}$ & $0.16^{* *}$ & 0.02 \\
\hline Positive coping & & & & & - & $0.21^{* *}$ & $0.32^{* *}$ \\
\hline Negative coping & & & & & & - & $0.28 * *$ \\
\hline Social coping & & & & & & & - \\
\hline
\end{tabular}


Despite the low and moderate value of the correlations, all of them were statistically significant. This could be attributed to the size of the sample. Also, most of the variables that were used as predictors did not have a high correlation to each other. However, moderate associations were found between prosocial behavior, social coping and positive coping, as well as between positive coping and social coping.

The results for the four regression models that were evaluated are presented in Table 3 . The first regression analysis indicated that Negative Coping did not make a significant and independent contribution to the model. Therefore, it was excluded from subsequent analyses.

The model that achieved the highest coefficient of determination was Model 4, which included four predictors: positive coping, social coping, emotion regulation and prosocial behavior. Also, the difference in percentage of explained variance between the last two regression models was minimal (see Table 3). The value obtained for the Durbin-Watson test (1.901) indicated independence error, so that there is no autocorrelation between the prediction errors of the models. Moreover, the significant values of the comparisons of the different models indicated that the association of the dependent variable is improved in each case. According to the t values, it can be concluded that the variables contribute to the models (see Table 4). With regard to the possibility of multicollinearity produced by the variable of prosocial behavior in Model 4, according to the values of the VIF, it can be concluded that, although there are moderate relationships with other variables, there is no risk of non-compliance with this assumption (see Table 4).

Table 3

Coefficients of Determination for the Predictive Models of Psychological Well-being

\begin{tabular}{lccccccc}
\hline \multicolumn{1}{c}{ Model } & $R$ & $R^{2}$ & $\begin{array}{c}R^{2} \\
\text { adjusted }\end{array}$ & SEE & $\begin{array}{c}F \\
\text { change }\end{array}$ & $p$ & $\begin{array}{c}\text { Durbin- } \\
\text { Watson }\end{array}$ \\
\hline $\begin{array}{l}\text { 1: (Constant), positive coping } \\
\text { 2: (Constant), positive coping, emotion regulation }\end{array}$ & 0.511 & 0.261 & 0.260 & 2.341 & 327.70 & $<0.001$ \\
$\begin{array}{l}\text { 3: (Constant), positive coping, emotion regulation, } \\
\text { social coping }\end{array}$ & 0.557 & 0.291 & 0.289 & 2.296 & 37.97 & $<0.001$ \\
$\begin{array}{l}\text { 4: (Constant), positive coping, emotion regulation, } \\
\text { social coping, prosocial behavior }\end{array}$ & 0.561 & 0.315 & 0.308 & 2.265 & 26.43 & $<0.001$ & 1.901 \\
\hline
\end{tabular}

Table 4

Coefficients of the Multiple Lineal Regression for Psychological Well-being

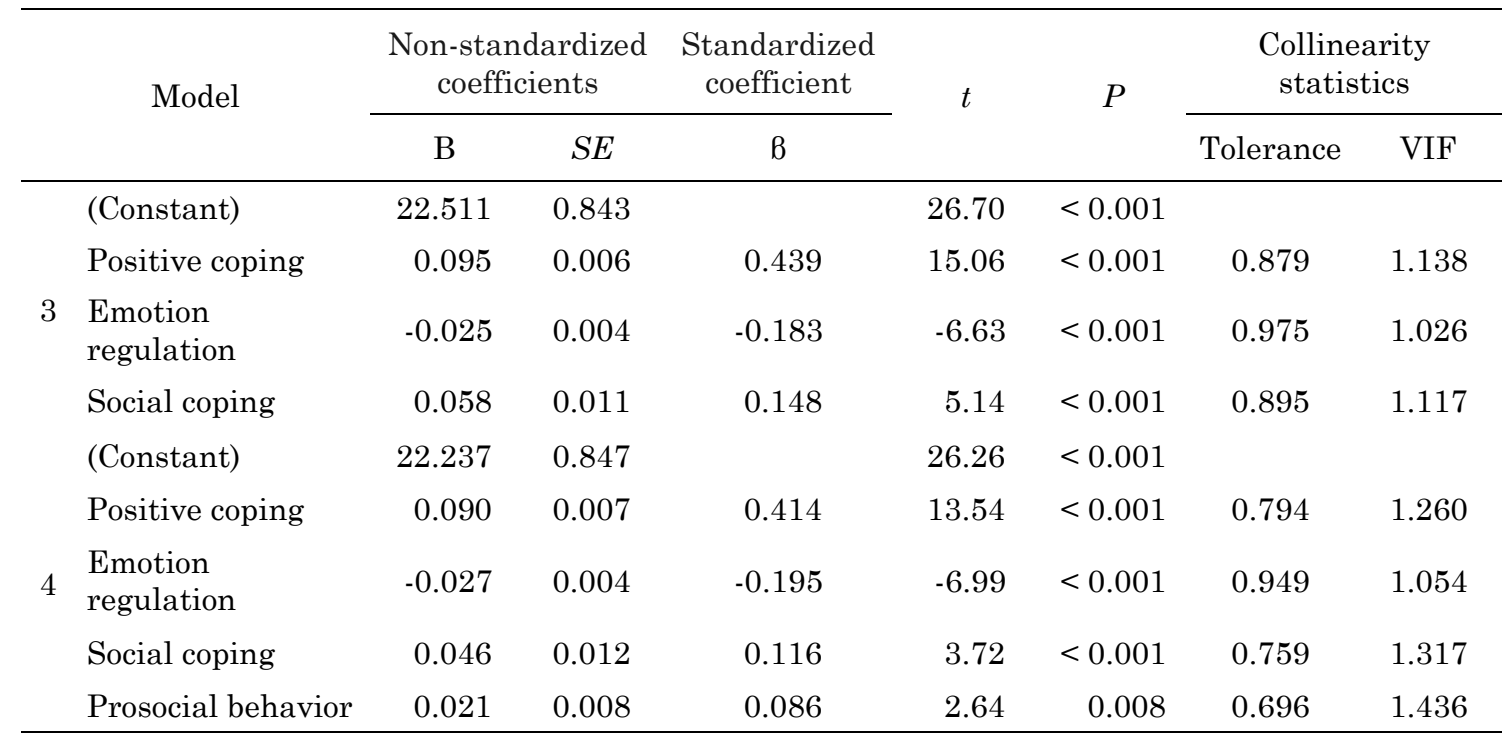


The results for the multiple linear regression for life satisfaction indicate that the model that explained the greatest proportion of variance (28\%) was Model 4, which included positive coping, social coping, emotion regulation, and prosocial behavior as predictors (see Table 5).

Table 5

Coefficients of Determination for the Predictive Models of Life Satisfaction

\begin{tabular}{lccccccc}
\hline \multicolumn{1}{c}{ Model } & $R$ & $R^{2}$ & $\begin{array}{c}R^{2} \\
\text { adjusted }\end{array}$ & $S E E$ & $F$ change & $p$ & $\begin{array}{c}\text { Durbin- } \\
\text { Watson }\end{array}$ \\
\hline $\begin{array}{l}\text { 1: (Constant), positive coping } \\
\text { 2: (Constant), positive coping, social coping }\end{array}$ & 0.429 & 0.184 & 0.183 & 10.242 & 209.62 & $<0.001$ \\
$\begin{array}{l}\text { 3: (Constant), positive coping, social coping, } \\
\text { emotion regulation }\end{array}$ & 0.521 & 0.271 & 0.269 & 9.690 & 35.66 & $<0.001$ & 1.873 \\
$\begin{array}{l}\text { 4: (Constant), positive coping, social coping, } \\
\text { emotion regulation, prosocial behavior }\end{array}$ & 0.532 & 0.283 & 0.280 & 9.618 & 14.94 & $<0.001$ \\
\hline
\end{tabular}

The value of the Durbin Watson test (1.873) suggested that there was no autocorrelation between model prediction errors. According to the $t$ values, all predictor variables contributed to the model. Also, there was no multicollinearity among the independent variables according to the values of the VIF, which in all cases were close to 1 (see Table 6).

Table 6 Coefficients of the Multiple Lineal Regression for Life Satisfaction

\begin{tabular}{|c|c|c|c|c|c|c|c|c|}
\hline & \multirow{2}{*}{ Model } & \multicolumn{2}{|c|}{$\begin{array}{l}\text { Non-stantardized } \\
\text { coefficients }\end{array}$} & \multirow{2}{*}{$\begin{array}{c}\begin{array}{c}\text { Standardized } \\
\text { coefficient }\end{array} \\
B\end{array}$} & \multirow{2}{*}{$t$} & \multirow{2}{*}{$p$} & \multicolumn{2}{|c|}{$\begin{array}{l}\text { Collinearity } \\
\text { statistics }\end{array}$} \\
\hline & & B & $S E$ & & & & Tolerance & VIF \\
\hline & (Constant) & 68.222 & 3.606 & & 18.92 & $<0.001$ & & \\
\hline & Positive coping & 0.256 & 0.028 & 0.283 & 9.06 & $<0.001$ & 0.794 & 1.260 \\
\hline \multirow[t]{3}{*}{4} & Social coping & 0.363 & 0.052 & 0.222 & 6.94 & $<0.001$ & 0.759 & 1.317 \\
\hline & $\begin{array}{l}\text { Emotion } \\
\text { regulation }\end{array}$ & -0.107 & 0.016 & -0.188 & -6.56 & $<0.001$ & 0.949 & 1.054 \\
\hline & Prosocial behavior & 0.130 & 0.034 & 0.129 & 3.87 & $<0.001$ & 0.696 & 1.436 \\
\hline
\end{tabular}

\section{Discussion}

The purpose of the present study was to assess the relation between positive competences (emotion regulation, proactive coping and prosocial behavior) and well-being and life satisfaction in Colombian adolescents. Multiple regression results indicated that the predictor variables explained around $31 \%$ of the variance of adolescents' well-being and, more specifically, that the variables that contributed the most were positive coping and social coping, followed by emotion regulation. These results are congruent with those obtained by Frydenberg and Lewis (2009) and Mayordomo-Rodríguez et al. (2015), who found that the use of active coping strategies, such as problem solving and seeking social support, is associated with adolescents' perceptions of well-being. Similarly, the results of this model coincide with those from studies that highlight an association between emotion regulation and well-being in adolescence (Haga et al., 2009).

The second outcome variable evaluated in this study was adolescents' life satisfaction. The proposed model explained $28 \%$ of its variance and the main predictor variables were positive and social coping and 
emotion regulation. However, prosocial behavior also showed an association with youths' perceived life satisfaction. These results coincide with findings from Gillham et al. (2011), who found a direct association between adolescents' well-being and both character strengths, self-regulation and competences that promote positive interactions with others. Furthermore, results in the current study provide evidence that highlights the need for more studies on positive aspects of adolescent development (Lippman et al., 2014).

\section{Limitations and Future Research}

One limitation of the study is that the assessed models included as predictors only individual variables. Recent literature in this area has called the attention to the association between interpersonal and contextual variables and individuals' perceived well-being. For instance, Lippman et al. (2014) and Thompson (2014) concluded that social competence to establish and maintain close relations with family members and friends is one important indicator of children and adolescents' well-being. The inclusion of variables that assess positive close relationships would be important for future research on adolescents' well-being.

A second limitation is related to the selected sample for the study. Even though sample size is adequate, the sampling procedure used was a convenience rather than a randomized one. As a result, the sample may not be representative of the adolescent population in the cities where the study was conducted. In future studies on predictors of youths' well-being it would be necessary to use a randomized sampling procedure in which adolescents from different groups (diverse regions and socioeconomic status) would be represented.

The type of instruments used in the present study constitute its third limitation. The instruments that measured the predictors as well as the outcome variables of the study were self-report scales. Given the exploratory purpose of this research which involved the assessment of different explanatory models of wellbeing in the Colombian context, self-report measures appeared to be adequate to explore adolescents' perceptions of those aspects of their lives. However, there is evidence in the literature about the need to reduce errors of variance, due to the use of common methods of assessment (e.g., self-report questionnaires) when evaluating predictors and outcome variables (Johnson, Rosen, \& Djurdjevic, 2011). Similarly, future studies should strive to include other sources of information (i.e., parents, teachers and peers), rather than relying only on adolescents' self-report, in order to understand factors associated with adolescents' life satisfaction and well-being. Most of the studies that assess well-being from a multidimensional approach have used quantitative methodologies based on multiple self-reported scales (González-Carrasco et al., 2019). Different authors highlight the advantage of using qualitative strategies, such as in-depth interviews or focus groups in research on children's perceptions of well-being. Recently, researchers that emphasize the active role of children on their own development have called the attention to the need of exploring the meanings of well-being from children's perspectives. This means that children should be selected as the main participants of the studies and be a part of both data gathering as well as data analysis processes. These authors invite researchers to conduct studies not only on children, but also with and by children (Mason \&Watson, 2014; Nic Gabhainn \& Sixsmith, 2006).

In the present study three specific positive competences were included as predictors of adolescents' well-being and life satisfaction. Future studies on the role of positive competences should evaluate the role of other variables, such as optimism. Chang (2001) suggested that optimism is an important variable to individuals' psychological functioning. There is broad evidence in recent literature on the association between optimism and well-being. Studies have shown that optimistic people respond to difficulties in more adapted ways and tend to take more advantage of life opportunities than pessimistic persons (Segerstrom, Carver, \& Scheier, 2017). Most of the studies that include optimism as a positive competence have used the Life Orientation Test-Revised (LOT-R) scale, which has shown good psychometric properties. This is also the case for studies conducted in Latin America (Vera-Villarroel, Córdova-Rubio, \& Celis-Atenas, 2009; Zenger et al., 2013). However, the evaluation of optimism in children and adolescents remains to be examined in future research.

Lastly, it is important to point out the need to develop measurement instruments to assess positive competences on the basis of the presence rather than the absence of the construct under evaluation. For instance, measuring emotion regulation instead of emotion dysregulation. This view fits better with the positive youth development approach and with the need to strengthen research on protective factors in adolescence. 
Summing up, future research studies on children's and adolescents' well-being should consider the use of mixed methodologies and longitudinal designs that include a variety of data gathering tools such as selfreport scales, interviews, observational records, drawings, photography, journals among others, as well as diverse sources of information (children, adolescents, parents, teachers and peers).

\section{Implications for Interventions and Policies}

Recent studies on mental health in Colombia have highlighted the need to develop both preventive interventions at different levels (primary, secondary) and health promotion strategies (Colombia, Ministerio de Salud, 2017; Colombia, Ministerio de Salud \& Colciencias, 2015). Among the proposed health promotion strategies, there are actions to foster individuals' resiliency and provide support within different systems, such as the school context, the family, and the community. Also, these studies conclude that health promotion requires the coordination of efforts among different governmental sectors: health, education, and labor (Colombia, Ministerio de Salud \& Colciencias, 2015).

Based on these directions for the development of future policies in Colombia, research on adolescents' mental health and development in this country should address questions regarding the promotion of positive competences, both at the intrapersonal and interpersonal levels within diverse contexts (e.g., family, schools) and their association with individuals' well-being. Furthermore, such research efforts should focus on moderating and mediating factors that explain their effects on adolescents' well-being. Such evidence should serve as a basis for the design and implementation of interventions to promote adolescents' well-being within different contexts.

The results presented in this manuscript are relevant to government policies for adolescent health promotion in Colombia, because they identify those competences (i.e., proactive coping and emotion regulation) that are more strongly associated with individuals' well-being during this developmental period. These findings represent an important input for the formulation and implementation of new programs and policies for adolescents. The promotion of health and well-being has been at the center of different policies oriented toward young people in Colombia. As an example, in 2005, the government formulated the National Policy for Youth for 2005-2015 (Presidencia de la República de Colombia, 2004), whose main objective was to propose a framework to understand young people and to orient academic and professional work to the promotion of adolescents' physical and mental health and well-being. In 2013, The Colombian Institute of Family Well-Being (in Spanish Instituto Colombiano de Bienestar Familiar [ICBF]) also established the guidelines of the program called "Generations with Well-Being", which aims to provide comprehensive services to children and adolescents, to prevent risks, and to promote their optimal growth and development (ICBF, 2013). However, the design of new programs and policies that focus on adolescents' strengths and promote their well-being are still needed in Colombia.

Based on the findings of the present study, the authors developed and piloted a school-based intervention to promote adolescents' well-being through the development of proactive coping, prosocial behavior, and emotion regulation skills among $7^{\text {th }}$ and $9^{\text {th }}$ graders (Carrillo, Gómez, Ripoll, \& Villada, 2018). Future research on health promotion programs in Colombia should consider the development of intervention strategies to foster individuals' competences that could be incorporated within the school curriculum and delivered by teachers and school counsellors. Positive experiences with regard to the integration of interventions into the school curriculum have been documented in Colombia (see Colombia, Ministerio de Educación, 2004), like the program to develop social competences for citizenship.

In conclusion, research-based policies to develop and strengthen adolescents' positive competences should be a priority in developing countries like Colombia. In particular, schools are important contexts to teach and promote the development not only of academic skills, but also social and emotional competences that contribute to children and adolescents' development and well-being (Arguís Rey, Bolsas Valero, Hernández Paniello, \& Salvador Monge, 2012; Seligman, Ernst, Gillham, Reivich, \& Linkins, 2009; Shoshani \& Steinmetz, 2014).

\section{References}

Alarcón Napurí, R. (2009). Psicología positiva: un enfoque emergente. Temática Psicológica, 18, 7-20. Retrieved from http://www.unife.edu.pe/publicaciones/revistas/revistas_postgrado/TEMATICA2008.pdf\#page=6 
Alfaro, J., Guzmán, J., Sirlopú, D., García, C., Reyes, F., \& Gaudlitz, L. (2016). Propiedades psicométricas de la Escala de Satisfacción con la Vida en los Estudiantes (SLSS) de Huebner en niños y niñas de 10 a 12 años de Chile. Anales de Psicología, 32, 383-392. https://doi.org/10.6018/analesps.32.2.217441

Arias Gallegos, W. L. (2013). Agresión y violencia en la adolescencia: la importancia de la familia. Avances en Psicología, 21, 23-34. Retrieved from http://revistas.unife.edu.pe/index.php/avancesenpsicologia/article/view/303/219

Antaramian, S. P., Huebner, E. S., \& Valois, R. F. (2008). Adolescent life satisfaction. Applied Psychology, 57(S1), 112-126. https://doi.org/10.1111/j.1464-0597.2008.00357.x

Arguís, R., Bolsas, A. P., Hernández, S., \& Salvador, M. M. (2012). Programa "Aulas Felices": psicología positiva aplicada a la educación (2nd ed.). Teruel, Spain: Centro Aragonés de Tecnologías para la Educación. Retrieved from http://cepgranada.org/ inicio/archivos/ar3061_programa\%20aulas\%20felices.pdf.

Ben-Arieh, A., Casas, F., Frønes, I., \& Korbin, J. E. (2014). Multifaceted concept of child well-being. In A. Ben-Arieh, F. Casas, I. Frønes, \& J. E. Korbin (Eds.), Handbook of child well-being: Theories, methods and policies in global perspective (pp. 1-27). New York, NY: Springer. https://doi.org/10.1007/978-90-481-9063-8 134

Bermúdez, M. P., Álvarez, I. T., \& Sánchez, A. (2003). Análisis de la relación entre inteligencia emocional, estabilidad emocional y bienestar psicológico. Universitas Psychologica, 2, 27-32. Retrieved from https://www.redalyc.org/pdf/647/64720105

Bowers, E. P., Geldhof, G. J., Johnson, S. K., Lerner, J. V., \& Lerner, R. M. (2014). Thriving across the adolescent years: A view of the issues. Journal of Youth and Adolescence, 43, 859-868. https://doi.org/10.1007/s10964-014-0117-8

British Council, Universidad del Rosario \& Universidad de los Andes Colombia (2018). Next generation Colombia: Amplificando la voz de los jóvenes. Bogotá, Colombia: British Council. Retrieved from https://www.britishcouncil.co/sites/default/files/next_generation_colombia__reporte_final.pdf

Caprara, G. V., Steca, P., Zelli, A., \& Capanna, C. (2005). A new scale for measuring adults' prosocialness. European Journal of Psychological Assessment, 21, 77-89. https://doi.org/10.1027/1015-5759.21.2.77

Carrillo, S., Gómez, Y., Ripoll, K., \& Villada, J. (2018). Promoción del bienestar en la adolescencia: Una experiencia desde la investigación y la intervención. Boletines Colpsic, 37, 3-8. Retrieved from http://www.colpsic.org.co/aym_image/files/BC_37_Salud.pdf

Casas Aznar, F., Buxarrais Estrada, M. R., Figuer Ramírez, C., González Carrasco, M., Tey Tejón, A., Noguera Pigem, E., \& Rodríguez Rodríguez, J. M. (2004). Los valores y su influencia en la satisfacción vital de los adolescentes entre los 12 y los 16 años: estudio de algunos correlatos. Apuntes de Psicología, 22, 3-23. Retrieved from https://hdl.handle.net/11441/84624

Casas, F., Bello, A., González, M., \& Aligué, M. (2012). Personal well-being among Spanish adolescents. Journal of Social Research \& Policy, 3(2), 19-45. Retrieved from https://www.unicef.es/sites/unicef.es/files/ARTICULO_Journal_of_Social_Research_Policy_Vol3_Iss2.pdf

Casas, F., Figuer, C., González, M., Malo, S., Alsinet, C., \& Subarroca, S. (2007). The well-being of 12- to 16-year-old adolescents and their parents: Results from 1999 to 2003 Spanish samples. Social Indicators Research, 83, 87-115. https://doi.org/10.1007/s11205-006-9059-1

Casas, F., Sarriera, J. C., Alfaro, J., González, M., Figuer, C., Abs da Cruz, D., Bedin, L., Valdenegro, B., y Oyarzún, D. (2014). Satisfacción escolar y bienestar subjetivo en la adolescencia: poniendo a prueba indicadores para su medición comparativa en Brasil, Chile y España. Suma Psicológica, 21, 70-80. https://doi.org/10.1016/S0121-4381(14)70009-8

Castellá Sarriera, J., Saforcada, E., Tonon, G., Rodríguez de La Vega, L., Mozobancyk, S., \& Bedin, L. M. (2012). Bienestar subjetivo de los adolescentes: un estudio comparativo entre Argentina y Brasil. Intervención Psicosocial, 21, 273-280. https://doi.org/10.5093/in2012a24

Casullo, M. M., \& Castro Solano, A. (2000). Evaluación del bienestar psicológico en estudiantes adolescentes argentinos. Revista de Psicología de la Pontificia Universidad Católica del Perú, 28, 36-68. Retrieved from http://revistas.pucp.edu.pe/index.php/psicologia/article/view/6840

Chang, E. C. (Ed.) (2001). Optimism \& pessimisms: Implications for theory, research, and practice. Washington, DC: American Psychological Association. https://doi.org/10.1037/10385-000

Cole, P. M., Martin, S. E., \& Dennis, T. A. (2004). Emotion regulation as a scientific construct: Methodological challenges and directions for child development research. Child Development, 75, 317-333. https://doi.org/10.1111/j.1467-8624.2004.00673.x

Colombia, Ministerio de Educación. (2004). Educación para vivir en sociedad. Al Tablero, 27. Retrieved from https://www.mineducacion.gov.co/1621/article-87284.html

Colombia, Ministerio de Salud. (2017). Boletín de Salud Mental: La salud mental de niños y adolescentes. Bogotá, Colombia: Minsalud- Todos por un país: Paz, Equidad, Educación. Retrieved from https://www.minsalud.gov.co/sites/rid/Lists/BibliotecaDigital/RIDE/VS/PP/ENT/boletin-4-salud-mental-nna-2017.pdf

Colombia, Ministerio de Salud y Colciencias (2015). Encuesta Nacional de Salud Mental. Bogotá, Colombia: Minsalud- Colciencias: Todos por un país: Paz, Equidad, Educación. Retrieved from http://www.odc.gov.co/Portals/1/publicaciones/pdf/consumo/estudios/nacionales/CO031102015salud_mental_tomoI.pdf

Damon, W. (2004). What is positive youth development? The Annals of the American Academy of Political and Social Science, 591, 1324. https://doi.org/10.1177/0002716203260092

De Castella, K., Goldin, P., Jazaieri, H., Ziv, M., Dweck, C. S., \& Gross, J. J. (2013). Beliefs about emotion: Links to emotion regulation, wellbeing, and psychological distress. Basic and Applied Social Psychology, 35, 497-505. https://doi.org/10.1080/01973533.2013.840632

Diener, E. (1984). Subjective well-being. Psychological Bulletin, 95, 542-575. Retrieved from http://labs.psychology.illinois.edu/ ediener/Documents/Diener_1984.pdf

Durlak, J. A. \& Weissberg, R. P. (2011). Promoting social and emotional development is an essential part of students' education. Human Development, 54, 1-3. https://doi.org/10.1159/000324337

Eisenberg, N., Fabes, R. A., \& Spinrad, T. L. (2006). Prosocial development. In W. Damon, R. M. Lerner \& N. Eisenberg (Eds.), Handbook of child psychology. Volume 3: Social, emotional, and personality development (6 ${ }^{\text {th }}$ ed., pp. 646-718). Hoboken, NJ: John Wiley \& Sons.

Frydenberg, E. \& Lewis, R. (2009). Relations among well-being, avoidant coping, and active coping in a large sample of Australian adolescents. Psychological Reports, 104, 745-758. https://doi.org/10.2466/PR0.104.3.745-758

Galindez, E., \& Casas, F. (2011). Adaptación y validación de la MSLSS de satisfacción vital multidimensional con una muestra de adolescentes, Revista de Psicología Social, 26(3), 309-323. https://doi.org/10.1174/021347411797361284 
Garaigordobil, M., \& García de Galdeano, P. (2006). Empatía en niños de 10 a 12 años. Psicothema, 18, 180-186. Retrieved from http://www.www.redalyc.org/articulo.oa?id=72718203

Garaigordobil, M., \& Oñederra, J. A. (2010). Inteligencia emocional en las víctimas de acoso escolar y en los agresores. European Journal of Education and Psychology, 3, 243-256. Retrieved from http://www.redalyc.org/articulo.oa?id=129315468008

Garbarino, J. (2014). Ecological perspective on child well-being. In A. Ben-Arieh, F. Casas, I. Frønes, \& J. E. Korbin (Eds.), Handbook of child well-being: Theories, methods and policies in global perspective (pp. 1365-1384). New York, NY: Springer.

Gillham, J., Adams-Deutsch, Z., Werner, J., Reivich, K., Coulter-Heindl, V., Linkins, M., Winder, B., Peterson, C., Park, N., Abenavoli, R., Contero, A., \& Seligman, M. E. P. (2011). Character strengths predict subjective well-being during adolescence. The Journal of Positive Psychology, 6, 31-44. https://doi.org/10.1080/17439760.2010.536773

Gilman, R., Huebner, E. S., \& Laughlin, J. E. (2000). A first study of the Multidimensional Students' Life Scale with adolescents. Social Indicators Research, 52, 135-160. https://doi.org/10.1023/A:1007059227507

González-Carrasco, M., Vaqué, C., Malo S., Crous, G, Casas, F., \& Figuer, C. (2019). A qualitative longitudinal study on the well-being of children and adolescents. Child Indicators Research, 12, 479-499. https://doi.org/10.1007/s12187-018-9534-7

Goswami, H. (2012). Social relationships and children's subjective well-being. Social Indicators Research, 107, 575-588. https://doi.org/10.1007/s11205-011-9864-z

Gratz, K. L., \& Roemer, L. (2004). Multidimensional assessment of emotion regulation and dysregulation: Development, factor structure, and initial validation of the Difficulties in Emotion Regulation Scale. Journal of Psychopathology and Behavioral Assessment, 26, 41-54. https://doi.org/10.1023/B:JOBA.0000007455.08539.94

Greenglass, E. R. (2002). Proactive coping and quality of life management. In E. Frydenberg (Ed.), Beyond coping: Meeting goals, visions, and challenges (pp. 37-62). New York, NY: Oxford University Press.

Greenglass, E. R., Schwarzer, R., \& Laghi, F. (2008). The Proactive Coping Inventory for Adolescents (PCI-A) [Online publication]. Toronto, Canada: York University. Retrieved from http://estherg.info.yorku.ca/greenglass-pci/

Greenglass, E., Schwarzer, R., Jakubiec, D., Fiksenbaum, L., \& Taubert, S. (1999, julio). The Proactive Coping Inventory (PCI): A multidimensional research instrument. Communication presented at the 20th International Conference of the Stress and Anxiety Research Society, Cracow, Poland. Retrieved from http://www.psych.yorku.ca/greenglass/pci.php

Gutiérrez-Doña, B., Greenglass, E., \& Schwarzer, R. (2002). Proactive Coping Inventory - Spanish version. Retrieved from http://userpage.fu-berlin.de/ health/pci_span.htm

Guzmán-González, M., Trabucco, C., Urzúa, A., Garrido, L., \& Leiva, J. (2014). Validez y confiabilidad de la versión adaptada al español del Cuestionario de Dificultades de Regulación Emocional (DERS-E) en población chilena. Terapia Psicológica, 31 , $19-29$. https://doi.org/10.4067/S0718-48082014000100002

Haga, S. M., Kraft, P., \& Corby, E. -K. (2009). Emotion regulation: Antecedents and well-being outcomes of cognitive reappraisal and expressive suppression in cross-cultural samples. Journal of Happiness Studies, 10, 271-291. https://doi.org/10.1007/s10902-007-9080-3

Hervas, G., \& Jodar, R. (2008). Adaptación al castellano de la Escala de Dificultades en la Regulación Emocional. Clínica y Salud, 19 (2), 139-156. Retrieved from http://scielo.isciii.es/pdf/clinsa/v19n2/v19n2a01.pdf

Huebner, E. S., Suldo, S. M., Smith, L. C., \& McKnight, C. G. (2004). Life satisfaction in children and youth: Empirical foundations and implications for school psychologists. Psychology in the Schools, 41, 81-93. https://doi.org/10.1002/pits.10140

Inderbitzen, H. M., \& Foster, S. L. (1992). The Teenage Inventory of Social Skills: development, reliability and validity. Psychological Assessment, 4, 451-459. https://doi.org/10.1037/1040-3590.4.4.451

Inglés, C.J., Méndez, F.X., Hidalgo, M.D., Rosa, A.I., \& Orgilés, M. (2003). Cuestionarios inventarios y escalas de ansiedad social para adolescentes: Una revisión crítica. Revista de Psicopatología y Psicología Clínica, 8, 1-21. https://doi.org/10.5944/rppc.vol.8.num.1.2003.3939

Inglés, C. J., Benavides, G., Redondo, J., García-Fernández, J. M., Ruiz-Esteban, C., Estévez, C., \& Huescar, E. (2009). Conducta prosocial y rendimiento académico en estudiantes españoles de educación secundaria obligatoria. Anales de Psicología, 25, 93101. Retrieved from http://www.redalyc.org/articulo.oa?id=16711594011

Inglés, C. J., Torregrosa, M. S., García-Fernández, J. M., Martínez-Monteagudo, M. C., Estévez, E., \& Delgado, B. (2014). Conducta agresiva e inteligencia emocional en la adolescencia. European Journal of Education and Psychology, 7, 29-41. https://doi.org/10.30552/ejep.v7i1.97

Instituto Colombiano de Bienestar Familiar [ICBF] (2013). Lineamiento técnico del programa de promoción y prevención para la protección integral de niños, niñas $y$ adolescentes "Generaciones con Bienestar". Retrieved from https://www.icbf.gov.co/sites/default/files/procesos/lm3.pp_lineamiento_tecnico_de_programa_de_p_y_p_para_la_proteccion_integ ral_de_nna_generaciones_con_bienestar_v1.pdf

Jadue, G. (2003). Transformaciones familiares en Chile: riesgo creciente para el desarrollo emocional, psicosocial y la educación de los hijos. Estudios Pedagógicos, 29, 115-126. https://doi.org/10.4067/S0718-07052003000100008

Johnson, R. E., Rosen, C. C., \& Djurdjevic, E. (2011). Assessing the impact of common method variance on higher order multidimensional constructs. Journal of Applied Psychology, 96, 744-761. https://doi.org/ 10.1037/a0021504

Kurtines, W. M., Ferrer-Wreder, L., Berman, S. L., Lorente, C. C., Briones, E., Montgomery, M. J., Albrecht, R., Garcia, A. J., \& Arrufat, O. (2008). Promoting positive youth development: The Miami Youth Development Project (YDP). Journal of Adolescent Research, 23, 256-267. https://doi.org/ 10.1177/0743558408314375

Lau, A. L. D., Cummins, R. A., \& McPherson, W. (2005). An investigation into the cross-cultural equivalence of the Personal Wellbeing Index. Social Indicators Research, 72, 403-432. https://doi.org/10.1007/s11205-004-0561-z

Lerner, R. M. (2005, September). Promoting positive youth development: Theoretical and empirical bases. Paper presented at the Workshop on the Science of Adolescent Health and Development, National Research Council, Washington, DC, United States.

Lerner, R. M., Almerigi, J. B., Theokas, C., \& Lerner, J. V. (2005). Positive Youth Development: A view of the issues. The Journal of Early Adolescence, 25, 10-16. https://doi.org/10.1177/0272431604273211

Lerner, R. M., Dowling, E. M., \& Anderson, P. M. (2003). Positive youth development: Thriving as the basis of personhood and civil society. In Furrow, J. and Wagener, L. (Eds.). [Special Issue]. Applied Developmental Science, 7 (3), $172-180$. https://doi.org/10.1007/s11205-004-0561-z

Lerner, R. M., Fisher, C. B., \& Weinberg, R. A. (2000). Toward a science for and of the people: Promoting civil society through the application of developmental science. Child Development, 71, 11-20. https://doi.org/10.1111/1467-8624.00113

Lerner, R. M., Lerner, J. V., von Eye, A., Bowers, E. P., \& Lewin-Bizan, S. (2011). Individual and contextual bases of thriving in adolescence: A view of the issues. Journal of Adolescence, 34, 1107-1114. https://doi.org/10.1016/j.adolescence.2011.08.001 
Levin, K. A., Dallago, L., \& Currie, C. (2012). The association between adolescent life satisfaction, family structure, family affluence and gender differences in parent-child communication. Social Indicators Research, 106, 287-305. https://doi.org/10.1007/s11205-011-9804-y

Lippman, L. H., Ryberg, R., Teerzian, M., Moore, K. A., Humble, J., \& McIntosh, H. (2014). Positive and protective factors in adolescent well-being. In A. Ben-Arieh, F. Casas, I. Frønes, \& J. E. Korbin (Eds.), Handbook of child well-being: Theories, methods and policies in global perspective (pp. 2823-2866). New York, NY: Springer.

Martorell, C., González, R., Ordóñez, A., \& Gómez, O. (2011). Estudio confirmatorio del Cuestionario de Conducta Prosocial (Ccp) y su relación con variables de personalidad y socialización. Revista Iberoamericana de Diagnóstico y Evaluación Psicológica, 2(32), 35-52. Retrieved from http://www.redalyc.org/articulo.oa?id=459645440003

Mason, J., \& Watson, E. (2014). Researching children: Research on, with, and by children. In A. Ben-Arieh, F. Casas, I. Frønes, \& J. E. Korbin (Eds.), Handbook of child well-being: Theories, methods and policies in global perspective (pp. 2757-2796). New York, NY: Springer.

Mayordomo-Rodríguez, T., Meléndez-Moral, J. C., Viguer-Segui, P., \& Sales-Galán, A. (2015). Coping strategies as predictors of wellbeing in youth adult. Social Indicators Research, 122, 479-489. https://doi.org/10.1007/s11205-014-0689-4

Mesurado, B. (2010). La experiencia de flow o experiencia óptima en el ámbito educativo. Revista Latinoamericana de Psicología, 42, 183-192. Retrieved from http://www.redalyc.org/articulo.oa?id=80515381001

Nic Gabhainn, S. \& Sixsmith, J. (2006). Children photographing well-being: Facilitating participation in research. Children \& Society, 20, 249-259. https://doi:10.1111/j.1099-0860.2005.00002.x

Oyanedel, J. C., Alfaro, J., Varela, J., \& Torres, J. (2014). ¿Qué afecta el bienestar subjetivo y la calidad de vida de las niñas y niños chilenos? Resultados de la Encuesta Internacional sobre Bienestar Subjetivo Infantil. Santiago, Chile: LOM. Retrieved from http://www.isciweb.org/_Uploads/dbsAttachedFiles/ISCWeBChile_2014.pdf

Padrós Blázquez, F., Gutiérrez Hernández, C. Y., \& Medina Calvillo, M. A. (2015). Propiedades psicométricas de la Escala de Satisfacción con la Vida (SWLS) de Diener en población de Michoacán (México). Avances en Psicología Latinoamericana, 33, 223232. https://doi.org/10.12804/apl33.02.2015.04

Peterson, C., \& Seligman, M. E. P. (2004). Character strengths and virtues: A handbook and classification. New York, NY: Oxford University Press/Washington, DC: American Psychological Association.

Pineda Roa, C. A., Castro Muñoz, J. A., \& Chaparro Clavijo, R. A. (2018). Estudio psicométrico de las Escalas de Bienestar Psicológico de Ryff en adultos jóvenes colombiano. Pensamiento Psicológico, 16(1), 45-55. https://doi.org/10.11144/ Javerianacali.PPSI16-1.epeb

Presidencia de la República de Colombia. (2004). Política Nacional de Juventud 2005-2015. Bogotá: Presidencia de la República. Retrieved from http://www.youthpolicy.org/national/Colombia_2005_National_Youth_Policy.pdf

Proctor, C. L., Linley, P. A., \& Maltby, J. (2009). Youth life satisfaction: A review of the literature. Journal of Happiness Studies, 10, 583-630. https://doi.org/10.1007/s10902-008-9110-9

Quiceno, J. M., \& Vinaccia, S. (2014a). Calidad de vida en adolescentes: análisis desde las fortalezas personales y las emociones negativas. Terapia Psicológica, 32, 185-200. https://doi.org/10.4067/S0718-48082014000300002

Quiceno, J. M., \& Vinaccia, S. (2014b). Calidad de vida, fortalezas personales, depresión y estrés en adolescentes según sexo y estrato. International Journal of Psychology and Psychological Therapy, 14, 155-170. Retrieved from http://www.redalyc.org/articulo.oa?id=56031293002

Roesch, S. C., Aldridge, A. A., Huff, T. L. P., Langner, K., Villodas, F., \& Bradshaw, K. (2009). On the dimensionality of the Proactive Coping Inventory: 7,5, 3 factors? Anxiety, Stress \& Coping, 22, 327-339. https://doi.org/10.1080/10615800802082304

Ryff, C. \& Keyes, C. L. M. (1995). The structure of psychological well-being revisited. Journal of Personality and Social Psychology, 69, 719-727. Retrieved from http://www.aging.wisc.edu/midus/findings/pdfs/830.pdf

Sagy, S., Eriksson, M., \& Braun-Lewensohn, O. (2015). The salutogenic paradigm. In S. Joseph (Ed.), Positive psychology in practice: Promoting human flourishing in work, health, education, and everyday life (2 ${ }^{\text {nd }}$ ed., pp. 61-80). Hoboken, NJ: John Wiley \& Sons. https://doi.org/10.1002/9781118996874.ch5

Salguero, J. M., Fernández-Berrocal, P., Ruiz-Aranda, D., Castillo, R., \& Palomera, R. (2011). Inteligencia emocional y ajuste psicosocial en la adolescencia: el papel de la percepción emocional. European Journal of Education and Psychology, 4, 143-152. Retrieved from http://www.redalyc.org/articulo.oa?id=129322659005

Segerstrom, S. C., Carver, C. S., \& Scheier, M. F. (2017). Optimism. In M. D. Robinson \& M. Eid (Eds.), The happy mind: Cognitive contribution to well-being (pp. 195-212). Cham, Switzerland: Springer. https://doi.org/10.1007/978-3-319-58763-9_11

Seligman, M. E. P. (2002). Positive psychology, positive prevention, and positive therapy. In C. R. Snyder \& S. J. Lopez (Eds.), Handbook of positive psychology (pp. 3-9) New York, NY: Oxford University Press.

Seligman, M. E. P., Ernst, R. M., Gillham, J., Reivich, K., \& Linkins, M. (2009). Positive education: Positive psychology and classroom interventions. Oxford Review of Education, 35, 293-311. https://doi.org/10.1080/03054980902934563

Seligman, M. E. P., \& Pawelski, J. O. (2003). Positive psychology: FAQs. Psychological Inquiry, 14, 159-163. Retrieved from https://www.jstor.org/stable/1449825

Shoshani, A., \& Steinmetz, S. (2014). Positive psychology at school: A school-based intervention to promote adolescents' mental health and well-being. Journal of Happiness Studies, 15, 1289-1311. https://doi.org/10.1007/s10902-013-9476-1

Slatcher, R. B., \& Trentacosta, C. J. (2012). Influences of parent and child negative emotionality on young children's everyday behaviors. Emotion, 12, 932-942. https://doi.org/10.1037/a0027148

Thompson, R. A. (2011). Emotion and emotion regulation: Two sides of the developing coin. Emotion Review, 3, 53-61. https://doi.org/10.1177/1754073910380969

Thompson, R. A. (2014). Why are relationships important to children's well-being? In A. Ben-Arieh, F. Casas, I. Frønes, \& J. E. Korbin (Eds.), Handbook of child well-being: Theories, methods and policies in global perspective (pp. 1917-1954). New York, NY: Springer. https://doi.org/10.1007/978-90-481-9063-8_134

Tomyn, A. J., \& Cummins, R. A. (2011). The subjective wellbeing of high-school students: Validating the Personal Wellbeing IndexSchool Children. Social Indicators Research, 101, 405-418. https://doi.org/10.1007/s11205-010-9668-6

Tuesca-Molina, R., Centeno Romero, H., de la Ossa Salgado, M., García Delgado, N., \& Lobo López, J. (2008). Calidad de vida relacionada con la salud y determinantes sociodemográficos en adolescentes de Barranquilla (Colombia). Salud Uninorte, 24, 5363. Retrieved from http://www.redalyc.org/articulo.oa?id=81724107 
Veenhoven, R. (1994). El estudio de la satisfacción con la vida. Intervención Psicosocial, 3(9), 87-116. Retrieved from https://core.ac.uk/download/pdf/18518704.pdf

Vera-Villarroel, P., Córdova-Rubio, N., \& Celis-Atenas, K. (2009). Evaluación del optimismo: un análisis preliminar del Life Orientation Test versión revisada (LOT-R) en población chilena. Universitas Psychologica, 8, 61-67. Retrieved from https://core.ac.uk/download/pdf/26749178.pdf

Vera-Villarroel, P., Urzúa, A., Pavez, P., Celis-Atenas, K., \& Silva, J. (2012). Evaluation of subjective well-being: Analysis of the Satisfaction with Life Scale in the Chilean population. Universitas Psychologica, 11, 719-727. Retrieved from http://www.scielo.org.co/pdf/rups/v11n3/v11n3a03.pdf

Verdugo-Lucero, J. L., Ponce de León-Pagaza, B. G., Guardado-Llamas, R. E., Meda-Lara, R. M., Uribe-Alvarado, J. I., \& GuzmánMuñiz, J. (2013). Estilos de afrontamiento al estrés y bienestar subjetivo en adolescentes y jóvenes. Revista Latinoamericana de Ciencias Sociales, Niñez y Juventud, 11, 79-91. Retrieved from http://www.redalyc.org/articulo.oa?id=77325885021

Viñas Poch, F., González Carrasco, M., García Moreno, Y., Malo Cerrato, S., \& Casas Aznar, F. (2015). Los estilos y estrategias de afrontamiento y su relación con el bienestar personal en una muestra de adolescentes. Anales de Psicología, 31, $226-233$. https://doi.org/10.6018/analesps.31.1.163681

Weinberg, A., \& Klonsky, E. D. (2009). Measurement of emotion dysregulation in adolescents. Psychological Assessment, $21,616-621$. https://doi.org/10.1037/a0016669

WHOQOL Group (1995). The World Health Organization Quality of Life Assessment (WHOQOL): Position paper from the World Health Organization. Social Science \& Medicine, 41, 1403-1409. https://doi.org/10.1016/0277-9536(95)00112-K

World Health Organization (2017). Adolescents and mental health. Genève, Switzerland: Author. Retrieved from http://www.who.int/maternal_child_adolescent/topics/adolescence/mental_health/en/

Ye, S., Yu, L., \& Li, K. K. (2012). A cross-lagged model of self-esteem and life satisfaction: Gender differences among Chinese university students. Personality and Individual Differences, 52, 546-551. https://doi.org/10.1016/j.paid.2011.11.018

Zenger, M., Finck, C., Zanon, C., Jimenez, W., Singer, S., \& Hinz, A. (2013). Evaluation of the Latin American version of the Life Orientation Test-Revised. International Journal of Clinical and Health Psychology, 13, 243-252. Retrieved from http://www.redalyc.org/articulo.oa?id=33727852009

Zuffianò, A., Martí-Vilar, M., \& López-Pérez, B. (2018). Prosociality and life satisfaction: A daily-diary investigation among Spanish university students. Personality and Individual Differences, 123, 17-20. https://doi.org/10.1016/j.paid.2017.10.042

Fecha de recepción: Mayo de 2018.

Fecha de aceptación: Diciembre de 2018. 